BIS WORKING PAPERS

No. 78 - October 1999

\title{
BANKING AND COMMERCE: \\ A LIQUIDITY APPROACH
}

\author{
by
}

Joseph G Haubrich and João A C Santos

BANK FOR INTERNATIONAL SETTLEMENTS

Monetary and Economic Department

Basel, Switzerland 
BIS Working Papers are written by members of the Monetary and Economic Department of the Bank for International Settlements, and from time to time by other economists, and are published by the Bank. The papers are on subjects of topical interest and are technical in character. The views expressed in them are those of their authors and not necessarily the views of the BIS.

Copies of publications are available from:

Bank for International Settlements

Information, Press \& Library Services

$\mathrm{CH}-4002$ Basel, Switzerland

Fax: +41 61 / 2809100 and +4161/2808100

This publication is available on the BIS website (www.bis.org).

(C) Bank for International Settlements 1999.

All rights reserved. Brief excerpts may be reproduced or translated provided the source is stated. 


\title{
BIS WORKING PAPERS
}

No. 78 - October 1999

\section{BANKING AND COMMERCE: A LIQUIDITY APPROACH}

\author{
by
}

Joseph G Haubrich and João A C Santos *

\begin{abstract}
This paper looks at the advantages and disadvantages of mixing banking and commerce, using the "liquidity" approach to financial intermediation. Bringing a non-financial firm into a banking conglomerate may be advantageous because it may make it easier for the bank to dispose of assets seized in a loan default. The internal market formed inside the banking and commerce conglomerate increases the liquidity of such assets and improves the bank's ability to perform financial intermediation. More generally, owning a non-financial firm may act either as a substitute or a complement to commercial lending. In some cases, a bank will voluntarily refrain from making loans, choosing to become a non-bank bank in an unregulated environment.
\end{abstract}

Joseph G Haubrich is with the Federal Reserve Bank of Cleveland and João A C Santos is with the Bank for International Settlements.

The authors thank George Pennacchi, Anil Kashyap, Rafael Repullo, Xavier Freixas, James Kolari, Will Roberts, Joe Bisignano, Craig Furfine, Kostas Tsatsaronis and participants at the 1999 Federal Reserve Bank of Chicago Bank Structure Conference, the University of Freiburg, the Bank for International Settlements, the 1999 JFI/CEPR conference, the 1999 EFMA, EFA and Summer Econometric meetings for useful comments. Part of this research was developed while João Santos was at the Federal Reserve Bank of Cleveland. The views stated herein are those of the authors and are not necessarily those of the Federal Reserve Bank of Cleveland or of the Board of Governors of the Federal Reserve System or of the Bank for International Settlements. 



\section{Contents}

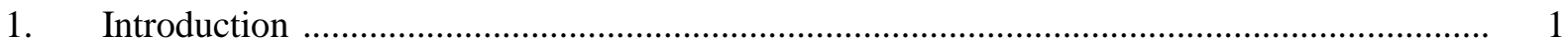

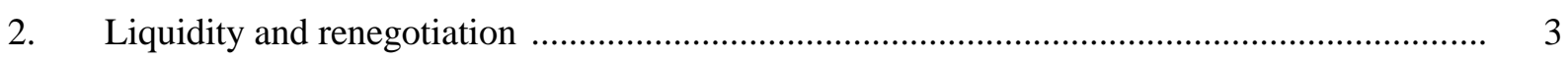

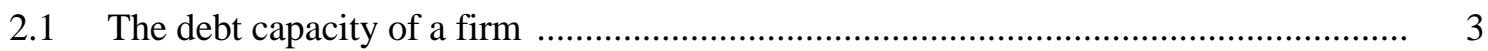

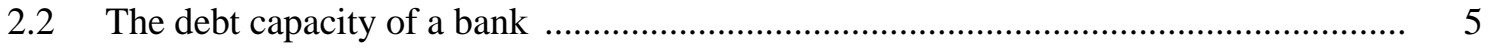

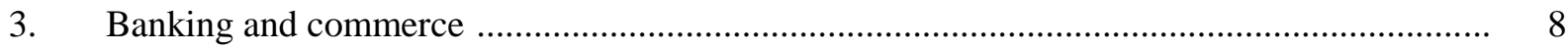

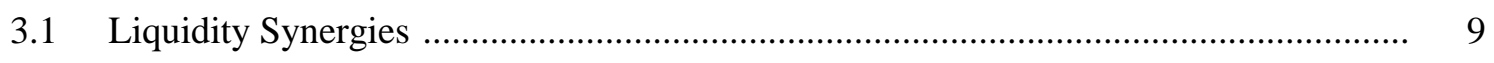

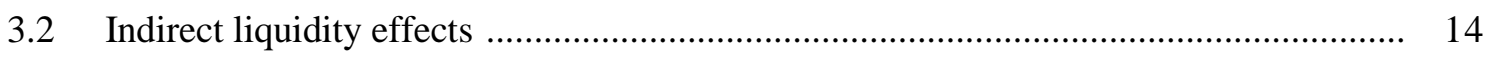

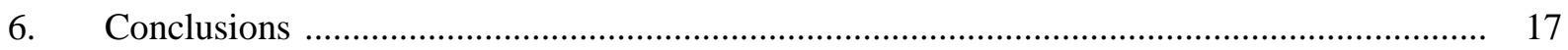

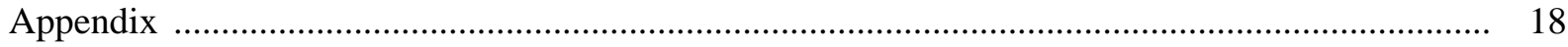

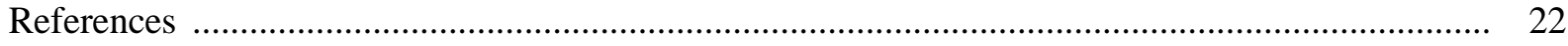





\section{Introduction}

The barrier preventing the merger of non-financial firms with banks is from one perspective the last frontier of financial deregulation, and as such it has received much attention, particularly in the United States. ${ }^{1}$ From another perspective, the barrier deserves attention precisely because it has been breached so often abroad and on several occasions throughout American history. ${ }^{2}$ And yet economic models mixing banking and commerce are rare, perhaps because current theories have little to say about the matter.

In this paper we hope to shed some light on the advantages and disadvantages of mixing banking with commerce using the "liquidity" approach to financial intermediation, pioneered in Myers and Rajan (1998), which combines the positive and negative aspects of liquidity. This results in a concern over a rather different set of questions than those considered by the more information-based models of debt and equity, such as Gorton and Haubrich (1987) or Santos (1999). We feel that the advantages in considering the meaning of control rights, the nature of the synergies and the role of liquidity will make up for the model's (current) inability to consider, for example, the questions addressed by those information-based models and diversification issues.

Most of the literature on banking and commerce has concentrated on the implications of a bank's equity position in a borrowing firm for that bank and the firm. For example, Pozdena (1991), Kim (1992), and John, John and Saunders (1994) study how a borrowing firm's incentives change when the financier uses equity in addition to debt to fund the firm. Boyd, Chang and Smith (1997) and Santos (1999) study the implications of equity stakes when funding is provided by a bank rather than a financier, in the presence of moral hazard caused by deposit insurance. Santos focuses on the mix of debt and equity as a means to control moral hazard on the part of borrowers. Boyd et al focus on bank monitoring to control a similar moral hazard problem. Rajan (1992) studies the impact of a financier's equity stake on his credibility as an underwriter. Puri (1996) studies the impact of that stake on the set of firms that the financier chooses to underwrite. Finally, Berlin, John, and Saunders (1996) examine the importance of a financier's equity stake in a firm that is in financial distress.

Besides the theoretical literature, there is a growing body of empirical research on banks' equity investments, most of it using data on Japanese and German banks. Researchers have studied the impact of bank equity stakes on: agency costs, availability and cost of funds to firms, and on firms' performance both in and out of financial distress.

\footnotetext{
For example, see Barth, Brumbaugh and Yago (1997).

2 For a characterisation of the regulations on banking and commerce abroad see Barth, Nolle, and Rice (1997) and for a review of banks' affiliation with non-financial firms throughout American history see Santos (1998).
} 
The previous literature misses a key aspect of intermediation identified by Myers and Rajan, namely, the interplay between the positive and negative aspects of liquidity. Their model treats banks as a special type of conglomerate; one combining a firm that takes in liquid deposits with a firm making illiquid loans. We extend the analysis to a broader class of conglomerates, that which combines banks with non-financial firms. This provides a way of thinking about what sort of banking-commerce conglomerates might arise and what the resulting firm might look like. We feel this provides a perspective that has been absent in previous discussions of banking and commerce.

In the Myers and Rajan model, a highly liquid firm, say, one handling cash and government securities, finds it hard to raise money because the possibilities of expropriation are so high. Making illiquid loans provides a way to bond the managers to the firm, as walking away in that case means giving up profits. In the standard Myers and Rajan model a bank would not merge with a non-financial firm, because the resulting conglomerate would always liquidate the bank's liquid assets and then ask its creditors for concessions through renegotiation. We show that a sufficient condition to reverse this result is the existence of particular synergies that would be lost if the firms in the conglomerate split up.

While several sources of synergies could be considered, we focus on those related to liquidity and identify some examples that lead to the formation of banking and commerce conglomerates. Of particular interest are the synergies that arise with the internal market formed inside the conglomerate for the assets underlying the bank loans. The internal market increases the liquidity of such assets, and thus makes it easier for the bank to dispose of them if it seizes them in a loan default. This improves the bank's ability to perform financial intermediation. As one example, consider a bank that makes auto loans and also owns a car-rental company or an auto dealership. This combination would make it easier for the bank to use or dispose of the collateral from loans that defaulted. Other examples of possible internal markets are also discussed.

We will also consider examples of synergies that have only indirect effects on the liquidity of the firms in the conglomerate. As before, the merger changes the overall liquidity of the firm, both by bringing in the less liquid firm and by adding the synergies. However, by allowing the synergy to take a very general form, we are able to identify cases where a conglomerate forms even when it loses liquidity and consequently the ability to extend loans. The merger can even lead the bank to end its lending business and become a non-bank bank, that is a firm that undertakes only half of the traditional banking function. If the loss in liquidity is less severe, however, the bank will continue to make loans, only fewer than before. The non-financial firm then acts as a substitute for loans. Conversely, if the resulting conglomerate is more liquid than the bank, it makes more loans than before, and owning a firm acts as a complement for loans. 
The remainder of the paper is organised as follows. The next section reviews the Myers and Rajan basic model. Section 3 presents our extension to that model. Section 4 concludes the paper with some final remarks.

\section{Liquidity and renegotiation: the basic model}

The model economy in this paper is an extension of that in Myers and Rajan (1998) and so our description of it is brief and limited to the results we find useful later on. Firms in the economy own a positive NPV investment opportunity. Each firm funds the project with a combination of funds owned by the entrepreneur and a loan from outside investors. Investors obtain repayment by threatening to liquidate the firm's assets. Entrepreneurs also contemplate the liquidation of the firm's assets. Liquidating the assets, however, may not attain their full value, perhaps because of "fire sale" effects, a "lemons" problem, bid-ask spreads, bankruptcy and enforcement costs, or general transactions costs. All agents in the economy are risk neutral and the interest rate is set equal to zero.

\subsection{The debt capacity of a firm}

Consider a firm with a project that lasts for two periods and requires an investment $I$ at date 0 . The project produces cashflows $C_{1}$ and $C_{2}$ at dates 1 and 2 respectively. These cashflows are known to everyone but not verifiable. The investment creates an asset worth $d_{1}$ and $d_{2}$ at dates 1 and 2 respectively. These are the values of the asset in its best alternative use. They do not take into account the liquidation or transformation costs. The project has a positive NPV, that is, $C_{1}+C_{2}+d_{2}>I$, and it pays to continue it at date 1 , that is, $C_{2}+d_{2} \geq \alpha d_{1}$, where $\alpha$ is the portion of the firm's assets that the entrepreneur gets when he liquidates them.

The firm finances the investment with funds from the owner $E$, and by borrowing an amount $B$ supported by promised payments $P_{1}$ and $P_{2}$ at dates 1 and 2 . Both borrower and lender contemplate seizing the asset. The borrower may want to transform the asset before making the promised payments to the lender, that is, either before date 1 (at date $1 / 2$ ) or before date 2 (at date $1 \frac{1 / 2}{2}$ ). The lender may also consider liquidating the asset if the borrower does not meet the promised payments at dates 1 and 2 . As explained before, in either case there is a cost of liquidating the asset. Whoever seizes the asset gets only $\alpha$ percent of its value. ${ }^{3}$

The next step is to determine the firm's debt capacity, the maximum amount it can borrow. We do this by solving the model backwards. At date 2 , the borrower either makes the promised payment $P_{2}$ or

3 Later on we will allow the borrower and the lender to get different percentages; they may have different information about the asset or may have different access to the market where the asset is liquidated. 
offers to make a lower payment. The best the lender can do is to threaten liquidation, in which case he gets $\alpha d_{2}$. Thus, the lender gets $\operatorname{Min}\left\{P_{2}, \alpha d_{2}\right\}$, and the borrower gets $C_{2}+d_{2}-\operatorname{Min}\left\{P_{2}, \alpha d_{2}\right\}$.

At date $1 \frac{1}{2}$, the borrower decides whether to transform the firm's assets and realise $\alpha d_{2}$ or to continue in business and generate the cashflow $C_{2}$ and the terminal value $d_{2}$. He continues if $C_{2}+d_{2}-\operatorname{Min}\left\{P_{2}, \alpha d_{2}\right\} \geq \alpha d_{2}$, implying that the maximum the lender can get at date 2 is

$$
V L_{2}=\operatorname{Min}\left\{C_{2}+d_{2}-\alpha d_{2}, \alpha d_{2}\right\}
$$

At date 1 , the borrower may either meet the promised payment $P_{1}$, or ask to renegotiate the payments agreed to at date 0 . The lender may either renegotiate and get $a C_{2}+V L_{2}$ over the loan's life, or seize the assets and get $\alpha d_{l}{ }^{4}$ Thus, the most the lender can get over the loan's life is

$$
V L_{1}=\operatorname{Max}\left\{a C_{2}+V L_{2}, \alpha d_{1}\right\}
$$

To see why this holds, suppose the borrower asks to renegotiate the payments. The lender either agrees to renegotiate or not. If he does not agree, he can liquidate the project's asset and guarantee himself $\alpha \mathrm{d}_{1}$. If he does agree to renegotiate, he gives up the right to liquidate the firm and with probability $a$ he gets to make a take-it-or-leave offer. In this case, he demands the entire cashflow the project generates in period 2, $C_{2}$, and the borrower can do no better than accept. If the borrower turns down the offer the project will not generate a cashflow in period 2 . With probability $(1-a)$ the borrower makes the take-it-or-leave-it offer. In this case he demands the entire second period cashflow, $C_{2}$, and for the reason presented above the lender can do no better than accept. On average they split the second period cashflow according to their relative bargaining power, thus explaining the $a C_{2}$ term in $V L_{1}$.

Let $V L_{1 / 2}$ be the total amount the borrower expects to pay the lender over the life of the contract. Then at date $1 / 2$ he continues the project if

$$
C_{1}+C_{2}+d_{2}-V L_{1 / 2} \geq \alpha d_{1}
$$

Therefore maximum amount the firm can borrow at date 0 is given by the following linear programming problem

$\operatorname{Max} B=P_{1}+P_{2}$

subject to

$$
\begin{aligned}
& P_{1}+P_{2} \leq C_{1}+C_{2}+d_{2}-\alpha d_{1} \\
& P_{1}+P_{2}, \leq \operatorname{Max}\left\{a C_{2}+\operatorname{Min}\left(C_{2}+d_{2}-\alpha d_{2}, \alpha d_{2}\right), \alpha d_{1}\right\} \\
& P_{2} \leq \operatorname{Min}\left\{C_{2}+d_{2}-\alpha d_{2}, \alpha d_{2}\right\}
\end{aligned}
$$

4 Myers and Rajan model renegotiation following the Hart and Moore (1992) model. They argue that the result here is an extension of Hart and Moore's lemma 1 and implicitly assume $E+B+C_{1}-I \geq P_{1}$. 
Following Myers and Rajan, we assume that $C_{2}$ is large enough and enough cash is available to front load debt payments in $P_{1}$ rather than $P_{2}$. Under these circumstances, constraint (6) is not binding, and constraint (5) becomes $P_{1}+P_{2} \leq \operatorname{Max}\left\{a C_{2}+\alpha d_{2}, \alpha d_{1}\right\}$. The maximum amount the firm can borrow is then given by

$$
B=\operatorname{Min}\{T, \operatorname{Max}(G, L)\}
$$

where: $T \equiv C_{1}+C_{2}+d_{2}-\alpha d_{1}, G \equiv a C_{2}+\alpha d_{2}$, and $L \equiv \alpha d_{1}$

$T$ follows from the transformation constraint at $t=1 / 2, G$ follows from the going concern constraint at $t=1$ and $L$ follows from the liquidation constraint at $t=1$. For different parameters, each of the three constraints will be binding. Note that if the transformation condition at date $1 / 2$ is not binding the project's debt capacity is increasing in its liquidity $\alpha$. However, if $T$ binds, then the project's debt capacity is decreasing in the project's liquidity; such a project is overly liquid ( $\alpha>\bar{\alpha}$ in Figure 1). If $G$ binds, the project's debt capacity depends on cash flows, as the lender cannot force payment. Such a project is deemed illiquid ( $\alpha<\hat{\alpha}$ in Figure 1). If $L$ binds, debt capacity is determined by the liquidation value, and the project is liquid ( $\hat{\alpha}<\alpha<\bar{\alpha}$ in Figure 1).

Figure 1

\section{Debt capacity of a firm}

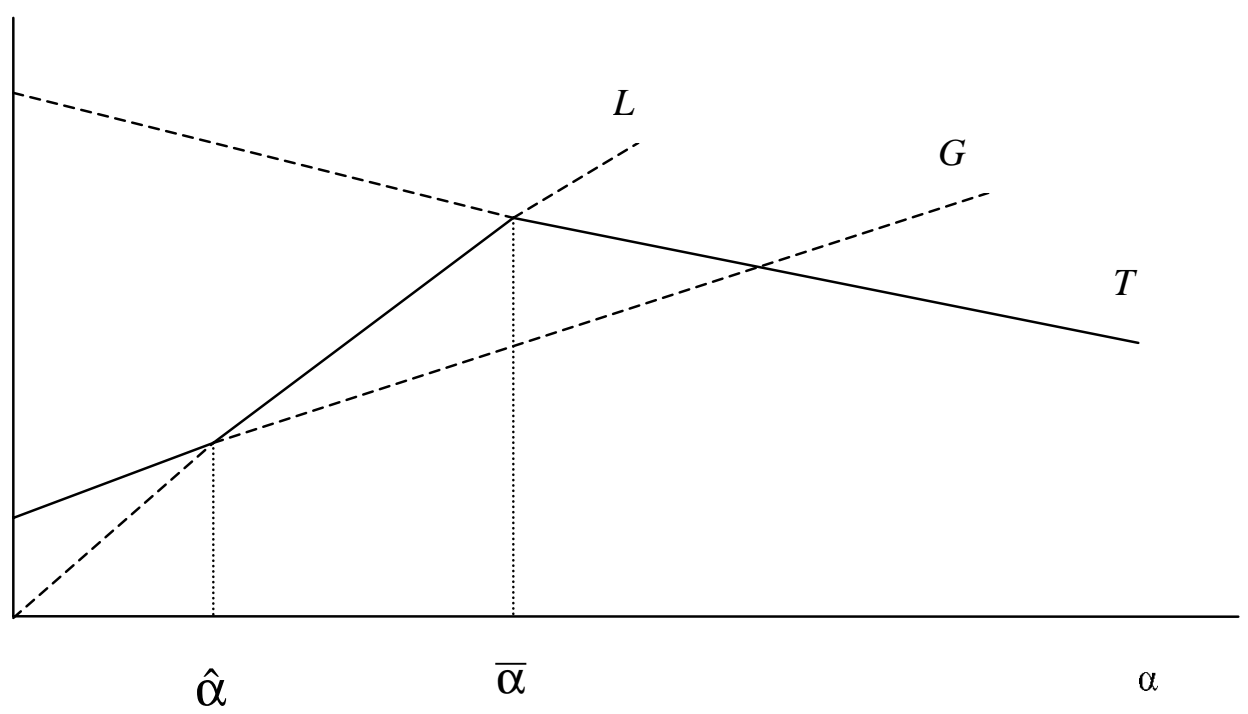

\section{$2.2 \quad$ The debt capacity of a bank}

This subsection shows that it is advantageous for overly liquid firms to act as banks, that is to raise money from investors and loan it to the illiquid or liquid firms, that is the non-financial firms in the economy. We present this analysis in some detail because closely related issues arise in understanding why a bank and a non-financial firm will merge. The analysis proceeds in three steps. The first step demonstrates that investors without a project cannot become intermediaries; they cannot raise the 
amount of money that is necessary to fund the loan. The second step shows that the bank, which combines its it overly liquid asset with a loan, can raise enough money from investors to fund the loan. Finally, the third step shows that non-financial firms can borrow more from a bank than from investors.

Following the analysis of the previous subsection, we know that for a firm with an illiquid or liquid project, defined here as a non-financial firm, $T^{f}>\operatorname{Max}\left\{G^{f}, L^{f}\right\}$, which implies a debt capacity equal to $B^{f}=\operatorname{Max}\left\{G^{f}, L^{f}\right\}$. Lets define this as firm $F$. Suppose that firm $F$ reaches an agreement with an investor whereby it promises to pay $\operatorname{him} P_{1}^{f}$ and $P_{2}^{f}$ if the investor lends the firm an amount $B^{f}=P_{1}^{f}+P_{2}^{f}$. What we are going to show now is that if the investor has no assets he will not be able to act as an intermediary. That investor will not be able to borrow enough money to support that loan, that is he will not be able to borrow $B^{f}$.

To see that, think of the loan extended to firm $F$ as an investment project and define it as project $L$. This project requires an initial investment, $I^{l} \equiv B^{f}$. It produces a cashflow at date $1, \mathrm{C}_{1}^{l} \equiv P_{1}^{f}$, and a cashflow at date $2, \mathrm{C}_{2}^{l} \equiv P_{2}^{f}$. It originates an asset worth $d_{1}^{l}$ and $d_{2}^{l}$ at dates 1 and 2 respectively. $d_{1}^{l} \equiv P_{2}^{f}$ because the owner of the loan (the owner of firm $L$ ) has already pocketed the loan's first period payment, $P_{1}^{f}$. Therefore, if the creditor to form $L$ seizes the firm's asset (the loan) at date 1 , he is entitled only to the loan's second period payment $P_{2}^{f} \cdot d_{2}^{l} \equiv 0$ because at date 2 both payments that the owner of the loan is entitled to have already occurred. Finally, in order to find how much money the owner of project $L$ can raise from investors we need to make an assumption about the secondary market for loans because this determines the liquidation value of the loan. Following Myers and Rajan we assume that there is no secondary market for loans.

Based on (7), the debt capacity of project $L$ is

$$
B^{l}=\operatorname{Min}\left\{T, \operatorname{Max}\left(G^{l}, L^{l}\right)\right\}
$$

where the going concern of the loan is $G^{l} \equiv a^{l} C_{2}^{l}+\alpha^{l} d_{2}^{l}=a^{l} P_{2}^{f}$. The transformation value of the loan is $T^{l} \equiv C_{1}^{l}+C_{2}^{l}+d_{2}^{l}-\alpha^{l} d_{1}^{l}=P^{f}+P_{2}^{f}$. The assumption that there is no secondary market for loans implies that $\alpha^{l}=0$ in that function. The liquidation value of the loan is $L^{l} \equiv \alpha^{l} d_{1}^{l}=P_{2}^{f}$. Recall that the liquidation value of a firm defines how much the creditor gets if he liquidates the firm at date 1 . If the creditor to firm $L$ liquidates that firm at date 1 he gets the firm's assets, the loan to firm $F$, which entitles him only to the loan's second period payment, $P_{2}^{f}$.

Based on those definitions, it is straightforward to see that $T>L^{l}>G^{l}$, thus implying that a firm whose only asset is the payment stream associated with a loan it has extended is always a liquid firm. (Notice the ambiguous terminology. It seems that a loan that cannot be sold should be illiquid, but 
formally it is liquid.) The debt capacity of such a firm is equal to $L^{l}$, which is smaller than $T^{1}$, the amount of money needed to fund the loan to firm $F$, since $B^{f}=T$. In sum, a firm with no assets other than a loan cannot raise enough money from investors to fund that loan.

Suppose now that the firm has an investment project of its own. What is its debt capacity when it combines that project with the loan to firm $F$ ? Will the incremental debt capacity be at least equal to the loan? Following Myers and Rajan, proposition 1, the answer to that question is yes, but only if the firm's project is overly liquid. That is, only firms with overly liquid investment projects can become financial intermediaries.

To see that, lets call the firm resulting from the combination of an overly liquid project with a loan to firm $F$, a bank, and identify the variables related to it with a superscript $b l$. The bank's transformation value is $T^{b l} \equiv T^{b}+T^{l}$, its going concern value is $G^{b l} \equiv G^{b}+G^{l}$, and its liquidation value is $L^{b l} \equiv L^{b}+L^{l}$. Based on (7), the bank's debt capacity is

$$
B^{b l}=\operatorname{Min}\left\{T^{b l}, \operatorname{Max}\left(G^{b l}, L^{b l}\right)\right\}
$$

It is easy to see that $B^{b l}$ can be equal to $T^{b l}$, meaning that the bank can raise enough money to fund its overly liquid project as before, that is $T^{b}$, and to make a loan equal to $T^{l}$ to firm $F$. The reason is that the bank's project is overly liquid, $T^{b}<\operatorname{Max}\left\{G^{b}, L^{b}\right\}$, and the loan is a liquid project $T^{l}>L^{l}>G^{l}$.

Key to that result is the fact that the bank will not selectively transform its overly liquid asset with the expectation of obtaining concessions from its creditors through renegotiation. The reason is that the bank knows its creditors are always better off immediately seizing the bank's loan to firm $F$ rather than renegotiating their claims. This follows from Myers and Rajan corollary 2. However, this would not be the case if the bank had chosen to merge with firm $F$. In this case, the bank would have an incentive to selectively liquidate its overly liquid asset. Because of this, the merger of the two firms would not be advantageous; they would be able to raise at most the sum of the amounts each of them could raise on their own.

Finally, to show that an overly liquid firm can act as a bank, we need to prove that it can make larger loans to other firms than the investors in the economy. Following Myers and Rajan we next argue that firm $F$ can (weakly) borrow more from the bank than from investors because the bank has more bargaining power than investors over the firm's cashflows in case there is renegotiation. That is $a_{B}^{f} \geq a_{I}^{f}$ (from now on where necessary, we will use the subscripts $B$ and $I$ to distinguish the variables that are bank and investor dependent). The difference in bargaining power may result from a better bargaining expertise of the bank or from free riding problems among the firm's creditors in case it borrows from several investors. Such a difference implies that the maximum amount that firm $F$ can borrow from the bank, $B_{B}^{f}=\operatorname{Max}\left\{G_{B}^{f}, L^{f}\right\}$, is greater or equal to the maximum amount it can borrow from investors, $B_{I}^{f}=\operatorname{Max}\left\{G_{I}^{f}, L^{f}\right\}$. Recall that only the going concern value of the firm, $G^{f}$, depends 
on the bargaining power of its creditors. The increased bargaining power also means that the bank can raise enough funds to finance the larger loan of size $B_{B}^{f}$ to firm $F$.

The Myers and Rajan model explains why a bank would rather lend than merge with a firm. The reason is that loans provide a way around the problem of selective liquidation and allow an overly liquid asset (of the bank) to combine with a less liquid asset (the loans) increasing the debt capacity of both. Therefore, their model in its original form does explain banking and commerce, that is the formation of conglomerates made of a bank, an overly liquid firm in the terminology of this paper, and a non-financial firm, a liquid or an illiquid firm. In the remainder of the paper we show, however, that their model can be extended to explain under what conditions such conglomerates are advantageous.

\section{Banking and commerce}

Most historians agree that banks arose from commercial merchant ventures (Shull 1983), and of the various reasons for mergers between banking and commerce (increased capital, diversification, economies of scale) the most interesting are the economies of scope, or synergies. One of the best descriptions of what this entails is by Chandler $(1977$, p.6) who argues that conglomerates were more likely to arise "when administrative coordination permitted greater productivity, lower costs, and higher profits than coordination by market mechanisms." Williamson (1985) gives examples of such control benefits, citing benefits from internal audits and the ability to employ very specific assets. Telling (1984) argues that putting financial centres in Sears' retail stores brought in customers who would not traditionally use financial services and infused Sears' tradition of customer service into the financial firms. John Jay Knox, Comptroller of the Currency from 1872 until 1884, referred to such "corporate culture" ideas when he reflected on the importance of private banks in the US "With the development of the interior counties, men of other businesses, such as land agents, general storekeepers, etc., transacted more or less of a banking business in connection with their regular business ... their knowledge of banking has been gained by hard experience, and as a class they are careful, shrewd, and substantial businessmen" (Knox, 1900 pp.777-8).

A more specific set of synergies was described by Alexander Todd, who started out delivering letters to miners and later sold out to Wells Fargo in 1853, when he explained the transformation from express company to bank (quoted in Loomis, 1968, p.6):

It was not long before the miners came to us to get us to take care of their money for them. It was a very common thing for me to start out from Stockton with two horses loaded down with gold dust. The miners had no opportunity for taking care of their dust, and we were obliged to have safes at our different offices, and our express business soon 
merged into a banking business. We charged them for taking care of their dust $1 / 2$ percent per month, and they gave us the privilege of using it also.

In order to have a viable model of banking and commerce, we must be able to answer several questions. Will the bank choose to own the non-financial firm rather than make a loan to it? Will the bank selectively transform its core overly liquid asset when combined with a non-financial firm? What effect will owning a non-financial firm have on the equilibrium number of loans undertaken by a bank? Is there a trade-off or are there down stream synergies as well?

We will consider two somewhat different sources of synergies that may be explored through the affiliation of banks with non-financial firms. First, we consider a specific example of a liquidity synergy, one that directly alters the bank's liquidation ability of certain assets-owning a non-financial firm allows the bank to form an internal market for certain assets, thus making it easier to dispose of them when they are seized in a loan default. Second, we consider what would happen if a synergy affected the cash flows and liquidation values of the separate projects. The first case emphasises how pure liquidity considerations will lead to the merging of banking and commerce. The second case emphasises how certain synergies will change the structure of the bank.

\subsection{Liquidity Synergies}

As we saw in the previous section, in the Myers and Rajan model (proposition 1) if the bank were to bring a liquid or illiquid firm in-house, its added debt capacity would never exceed (and might be lower than) the debt capacity of that firm on its own. Consequently, it would not be optimal for banking and commerce conglomerates to form. In this section, we show, however, that the Myers and Rajan model can be extended to explain banking and commerce conglomerates. A necessary (but not sufficient) condition for these conglomerates to be advantageous is the existence of synergies or positive externalities associated with the presence of a non-financial firm in the conglomerate.

Suppose that by owning a firm in a given sector the bank learns more information about that sector. The bank can use that information if it needs to liquidate the assets of a firm in the same sector to which it has extended a loan. Alternatively, the synergy could result not from new information but from the bank's ability to use the assets it seized in its own firm, rather then having to sell them. Upstream synergies are yet another possible example. Suppose a bank owns a firm that produces a product used as an input by other firms. If the bank extends loans to these firms, then on default it will get the asset produced by its in-house firm. Under these circumstances the bank can sell that asset to its in-house firm and avoid, at least partially, the costs of finding a third party buyer.

The aspect common to all these examples is that a conglomerate made of a bank and a non-financial firm creates an internal market for the assets underlying the loans extended by the bank. That market increases the liquidity of the assets, leading to an increase in the debt capacity of the bank in the 
conglomerate. In terms our model's parameters, this is an increase in $\alpha^{f}$, the fraction of the assets underlying the loan that the bank recovers in case of their liquidation. The more opaque, difficult to evaluate, or industry specific those assets are, the larger is the opportunity cost of not forming the conglomerate.

Historically, such an internal market seems to have played some role in the mixing of banking and commerce. Before the 1970 amendments to the Bank Holding Company Act closed the one-bank holding company loophole, banks engaged in a variety of non-financial activities. The House Committee on Banking and Currency (1969) found 397 banks engaged in non-financial businesses, 165 in real estate activities such as building, operating and leasing, 41 in various types of farming, 4 in public warehousing. All these activities can quite likely create an internal market.

Note, however, that because conglomerates cannot commit to not selectively transform their assets, the existence of synergies is not a sufficient condition for the formation of banking and commerce conglomerates. Even though there is no secondary market for loans, the conglomerate could transform the very liquid assets of the bank and renegotiate the assets of the non-financial firm. As we will see, there is a minimum size for the bank's portfolio of loans in order for a banking and commerce conglomerate to be sustainable, that is to avert selective liquidation. One nice point of this approach is that the synergies resulting from combining a bank with a non-financial firm are of a liquid nature, the same critical element that distinguishes banks from other firms in the model.

To show the implications of the liquidity synergy, suppose that there are many firms in the economy identical to firm $F$ of the previous section, that is with a liquid or illiquid investment project. Suppose also that there is a bank in the economy, that is a firm with an overly liquid project like that of firm $B$ in the previous section. Under these circumstances, there is a maximum number of loans of a size $B_{B}^{f}$ that the bank can extend. Ignoring integer constraints, that number is given by

$$
T^{b}+n^{*} B_{B}^{f}=\operatorname{Max}\left\{G^{b}+n^{*} G^{l}, L^{b}+n^{*} L^{l}\right\}
$$

where: $T^{b} \equiv C_{1}^{b}+C_{2}^{b}+d_{2}^{b}-\alpha^{b} d_{1}^{b}, G^{b} \equiv a_{I}^{b} C_{2}^{b}+\alpha^{b} d_{2}^{b}$, and $L^{b} \equiv \alpha^{b} d_{1}^{b}$. Each loan extended by the bank, $B_{B}^{f} \equiv \operatorname{Max}\left\{a_{B}^{f} C_{2}^{f}+\alpha^{f} d_{2}^{f}, \alpha^{f} d_{1}^{f}\right\}$, is supported by payments $P_{1}^{f}$ and $P_{2}^{f}$, with $P_{2}^{f}=\alpha^{f} d_{2}^{f}$ and $P_{1}^{f}=B_{B}^{f}-P_{2}^{f}$. Therefore, $G_{I}^{l} \equiv a_{I}^{l} P_{2}^{f}$, and $L^{l} \equiv \operatorname{Min}\left\{P_{2}^{f}, \alpha^{f} d_{2}^{f}\right\}$. Recall that $P_{2}^{f}=\alpha^{f} d_{2}^{f}$.

Note that at period 1, in case they seize a loan bank's creditors are entitled only to the loan's second period payment, $P_{2}^{f}$, because at that time the firm has already made the first period payment, $P_{1}^{f}$, to the bank. ${ }^{5}$ If the bank's creditors are not as able as the bank in liquidating the assets of a firm $F$, one

5 We could generalise this result and introduce an additional cost of liquidating $P_{2}^{f}$, but that would complicate matters without providing much illumination. 
could define new terms $\alpha_{I}^{f} \leq \alpha_{B}^{f}$, and this would be taken into account in the period 1 renegotiation between the bank and its creditors and it would reduce the value of $L_{I}^{l}$. To simplify, we assume that $\alpha_{B}^{f}=\alpha_{I}^{f}$ and drop the subscripts. This implies that the conglomerate's creditors will also benefit from the liquidity synergy, though this will happen only if the creditors gain control of the entire conglomerate.

Suppose now that the bank affiliates with a non-financial firm. We identify the variables associated with that firm with a superscript c. Because it is a liquid or an illiquid firm, we have $T^{c}>\operatorname{Max}\left\{G^{c}, L^{c}\right\}$. This implies that firm $C$ 's debt capacity is $B_{B}^{c}=\operatorname{Max}\left\{G^{c}, L^{c}\right\}$, when it borrows from a bank. As discussed previously, if there were no synergies it would not be advantageous to form such a conglomerate. Suppose, however, that by affiliating with this firm, the bank is able to explore a synergy like that described above.

Proposition 1: if by affiliating with a particular firm the bank can liquidate the assets underlying the loans it extends to other firms more easily then when it has to sell them in the market, that is, it leads to an increase in $\alpha^{f}$, then:

(i) the liquidity synergy may lead to an increase in the debt capacity of the bank, thus making the formation of the banking and commerce conglomerate advantageous;

(ii) selective transformation will not be optimal if the bank's portfolio of loans is sufficiently large.

Proof: see the Appendix.

To understand why that synergy helps the bank increase its debt capacity, remember that the reason loans work well when combined with the bank's overly liquid asset is because they are illiquid from the point of view of the bank (lacking a secondary market, the bank gets nothing if it attempts to transform its loans) but they are valuable when seized by the bank's creditors, thus giving them bargaining power. However, for a loan of a given size, that bargaining power varies with the distribution over time of the loans promised payments. At the extreme, if all the payments the loan promises to make are concentrated in period 1, this reduces the bank's incentive to transform its assets at period $1 / 2$, but it gives little bargaining power to bank creditors because by the time they expect to receive the first payment from the bank (period 1) the bank has already pocketed the loan's payment. This reduces creditors' willingness to lend to the bank, reducing its debt capacity.

The bank can solve that problem if it can structure the loan so that most of the proceeds arrive in period 2. This, however, is credible only if the bank has bargaining power over the assets of the firm at period 2, that is, if it can get a large fraction of the firm's asset at that point in time. This bargaining power is given by the liquidity of the firm's assets at period 2, which is in turn determined by the 
nature of the assets and by the bank's ability to sell them. In terms of the parameters of the model, that bargaining power determines the value of $\alpha^{f}$.

Thus, increasing $\alpha^{f}$, that is, increasing the liquidity of the assets of a firm, improves the bargaining power of the bank's creditors, which increases their willingness to lend to the bank. The bank can do that by creating an "internal market" for that underlying asset, thus avoiding the costs of selling it in the marketplace.

\section{A numerical example}

The liquidity synergy discussed above comes out clearly in a numerical example. We base our example on the extended example given in Myers and Rajan (1998).

The parameters of the investment project of the bank are $C_{1}^{b}=1, C_{2}^{b}=1, d_{1}^{b}=5, d_{2}^{b}=4$, and $a_{I}^{b}=0.5$. To simplify we assume that $\alpha^{b}=1$, (recall that the bank and its creditors get the same fraction of the bank's assets if either one of them liquidates these assets). We find that $T^{b}=1$, $G^{b}=4.5$, and $L^{b}=5$. Since the bank is an overly liquid firm, its debt capacity is $B_{I}^{b}=1$.

The parameters of the investment project of a non-financial firm $F$ are $C_{1}^{f}=1, C_{2}^{f}=1, d_{1}^{f}=2$, $d_{2}^{f}=1$, and $a_{B}^{f}=0.5$. We assume $\alpha^{f}=0.3$, implying that $T^{f}=2.4, G^{f}=0.8$, and $L^{f}=0.6$. These nonfinancial firms are illiquid firms. Their capacity is $B_{B}^{f}=0.8$. When the bank extends a loan $B{ }_{B}^{f}=0.8$ to one of these firms it charges $P_{1}^{f}=0.5$ in period 1 and $P_{2}^{f}=0.3$ in period 2.

The parameters of a loan extended by the bank are $C_{1}^{l}=0.5, C_{2}^{l}=0.3, d_{1}^{l}=0.3, d_{2}^{l}=0$, and $a_{I}^{l}=0.5 . \alpha_{B}^{1}=0$ because there is no secondary market for the loan. $\alpha_{I}^{l}=1$ because there is no cost for the bank's creditors when they threaten to cease the loan in the period 1 renegotiation. Therefore, $T^{l}=0.8, G^{l}=0.15$ and $L^{l}=0.3$. Based on these values and (10), we find that the maximum number of loans of size $B_{B}^{f}=0.8$ that the bank can extend is $n^{*}=8$. The bank's debt capacity is 7.4.

Suppose now that the bank merges with a non-financial firm. The parameters of this firm are equal to those of the non-financial firms presented above. We use a superscript $c$ to distinguish these parameters from those associated to firms $F$. Therefore, we have $C_{1}^{c}=1, C_{2}^{c}=1, d_{1}^{c}=2, d_{2}^{c}=1$, $a_{B}^{c}=0.5$, and $\alpha_{B}^{c}=\alpha_{C}^{c}=0.3$. As we saw above if this firm were to borrow from a bank it would be able to borrow 0.8 units because $T^{c}=2.4, G^{c}=0.8$, and $L^{c}=0.6$. In the absence of synergies, and leaving aside the problems of selective liquidation for a moment, we find that the transformation value of the conglomerate is $T^{b l c}=3.4+0.8 n$, its going concern is $G^{b l c}=5.3+0.15 n$, and its liquidation value is $L^{b l c}=5.6+0.3 n$. Using these definitions in (10) we find that the maximum number of loans of 
size $B_{B}^{f}=0.8$ and that the bank in the conglomerate can extend is $n^{*}=4.4$, in which case the conglomerate's debt capacity is 6.92. Forming the banking and commerce conglomerate is not advantageous under these circumstances.

Let us assume that bringing the non-financial firm in-house leads to a liquidity synergy of the form discussed above, that is, it makes it easier to liquidate the assets underlying the loans the bank extends to firms $F$. This leads to an increase in $\alpha^{f}$. Let us define $\tilde{\alpha}^{f}$ as the new value for that variable resulting from the synergy. The new transformation, going concern and liquidation values for the conglomerate, assuming that the bank does not change the size of the loan it extends to each firm $F$, are

$\tilde{T}^{b l c}=T^{b}+T^{c}+n T^{l}=3.4+0.8 n$

$\tilde{G}^{b l c}=G^{b}+G^{c}+a_{I}^{l} n \tilde{P}_{2}^{f}=5.3+0.5 n \tilde{\alpha}^{f}$

$\tilde{L}^{b l c}=L^{b}+L^{c}+n \tilde{P}_{2}^{f}=5.6+\mathrm{n} \tilde{\alpha}^{f}$

Given that $\tilde{L}^{b l c}>\tilde{G}^{b l c}$, then the bank in the conglomerate will be able to fund the same eight original loans if $\tilde{\alpha}^{f} \geq 0.525$. Suppose that $\tilde{\alpha}^{f}=0.525$. In this case, bringing the non-financial firm in-house gives the conglomerate the opportunity to raise enough money to fund the same eight loans to firms $F$ as before, and to fund the bank's core project and firm's $C$ investment project with the same amounts as before, and still have some funds left. The debt capacity of the conglomerate when it funds eight loans is 9.8 , which exceeds the sum of the debt capacities of the bank with eight loans, 7.4 , and that of firm $C$ when it raised money on its own, 0.8 .

Now we show that selective transformation will not occur. Following (A.5) we have $4<5.1$. Therefore, selective transformation will not occur at period $1 \frac{1 / 2}{2}$. Now move back to period $1 / 2$. If the conglomerate chooses not to selectively liquidate, assuming that it makes all the loans it can, that is, until it stops being an overly liquid firm, then we have $n^{*}=8$, in which case the conglomerate receives $\alpha^{b} d_{1}^{b}+\alpha^{c} d_{1}^{c}=5.6$. If the conglomerate chooses instead to selectively liquidate the bank's core project then it gets only $\alpha^{\mathrm{b}} d_{1}^{b}=0.6$, because the conglomerate's creditors will not renegotiate their claims. This follows from (A.6) because we have $6>\operatorname{Max}\{2,3\}$. As a result, the conglomerate will not selectively transform its assets at period $1 / 2$ either.

Above we discussed some general examples that could lead to the type of synergy considered here. The association of a bank and a non-financial firm creates an internal market for the assets underlying the loans extended by the bank. Wells Fargo, for example, with its expertise in transporting and assaying gold would find it easy to dispose of gold dust seized from a defaulting miner.

Mixing banking with commerce is advantageous in the model presented here because it liquifies the assets underlying the loans extended by the bank without increasing the liquidity of these loans. Given 
the important allocative role of internal capital markets in many conglomerates (c.f. Lamont (1997), Houston, James and Marcus (1997)) more general combinations remain a possibility.

\subsection{Indirect liquidity effects}

Looking at what happens when the synergy alters cash flows and underlying asset values requires a slightly different approach. We assume that making a loan to the project will not result in the synergy. Only if the bank owns the project and brings it "in-house" will the synergy effects occur. ${ }^{6}$ This assumption is in line with others often made in the literature. For example, Boyd, Chang and Smith (1997) assume that equity investment allows investors to share in the project's perquisite consumption, whereas debt investment does not. Secondly, we assume that this effect decreases as more projects are added to the bank's core project. In the model we specialise this even more and assume only the first added non-financial firm has synergistic effects. Ideally, of course, a model would specify why these effects occur, but we feel that this is secondary to understanding the liquidity aspects.

Since the model is already stylised we will consider a synergy of a specialised type. Combining the non-financial firm with the bank will increase the output of the investment projects of both entities in a particular way. The second period cash flow of the bank's project increases to $C_{2}^{b}+s_{2}^{b}$. In addition, the first period liquidation value of the non-financial firm's project increases to $d_{1}^{c}+s_{1}^{c}$.

That synergy has two important effects. By taking the project in-house, the bank obtains synergies that would not occur if it simply made a loan to the project. The bank also has an incentive not to selectively liquidate the project, because it would lose the synergies. In the basic Myers and Rajan model, a bank does not affiliate with a non-financial firm because the bank would transform its overly liquid project and renegotiate the debt payments.

Now consider what happens if the bank brings the non-financial firm in-house and gains the synergies. For now we simply assume that the bank will not selectively liquidate either project. Then the transformation value of the conglomerate is $T^{b c}=C_{1}^{b}+C_{2}^{b}+s_{2}^{b}+d_{2}^{b}-\alpha^{b} d_{1}^{b}+C_{1}^{c}+C_{2}^{c}+d_{2}^{c}-$ $\alpha^{c}\left(d_{1}^{c}+s_{1}^{c}\right)$. The going concern value of it is $G^{b c}=a_{I}^{b}\left(C_{2}^{b}+s_{2}^{b}\right)+\alpha^{b} d_{2}^{b}+a_{I}^{c} C_{2}^{c}+\alpha^{c} d_{2}^{c}$. The liquidation value of it is $L^{b c}=\alpha^{b} d_{1}^{b}+\alpha^{c}\left(d_{1}^{c}+s_{1}^{c}\right)$. Following (7) we find that the debt capacity of the conglomerate is

$$
B^{b c}=\operatorname{Min}\left\{T^{b c}, \operatorname{Max}\left(G^{b c}, L^{b c}\right)\right\}
$$

6 Clearly, in some cases debt financing can also bring control, and presumably the benefits would accrue in such cases. While perhaps important in the past, the equitable subordination doctrine makes it less relevant today. 
Why is direct investment better than a loan? Tautologically, because it is more profitable to bring the non-financial firm in-house rather than to make a loan to the firm. Therefore, we must have

$$
C_{1}^{b}+C_{2}^{b}+s_{2}^{b}+d_{2}^{b}+C_{1}^{c}+C_{2}^{c}+d_{2}^{c}-B^{b c} \geq C_{1}^{b}+C_{2}^{b}+d_{2}^{b}+P_{1}^{c}+P_{2}^{c}-B^{b l}
$$

where $P_{1}^{c}$ and $P_{2}^{c}$ are the payments that the bank receives from the non-financial firm $C$ in return for the loan it extended to that firm, and $B_{I}^{b l}$ is the amount that the bank borrows from the investors in the economy. In the case where the conglomerate remains an overly liquid firm, $B^{b c}=C_{1}^{b}+C_{2}^{b}+s_{2}^{b}+$ $d_{2}^{b}-\alpha^{b} d_{1}^{b}+C_{1}^{c}+C_{2}^{c}+d_{2}^{c}-\alpha_{B}^{c}\left(d_{1}^{c}+s_{1}^{c}\right)$. Assuming that the bank also remains overly liquid after it makes the loan, we have $B^{b l}=C_{1}^{b}+C_{2}^{b}+d_{2}^{b}-\alpha^{b} d_{1}^{b}+P_{1}^{c}+P_{2}^{c}$. Recall that we continue to assume there is no secondary market for loans. Under these circumstances, (12) reduces to:

$$
\alpha^{b} d_{1}^{b}+\alpha^{c}\left(d_{1}^{c}+s_{1}^{c}\right) \geq \alpha^{b} d_{1}^{b}
$$

which holds as long as the synergy $s_{1}^{c}$ is not too negative. ${ }^{7}$

Selective liquidation places further constraints on the values of $s_{1}^{b}$ and $s_{2}^{b}$. The conglomerate has a real temptation to transform its overly liquid core project and renegotiate the payments on the other project. Losing the synergy payoffs may make the selective transformation unprofitable, however.

What can we say about the conglomerates that might form? We characterise the most salient features in proposition 2.

\section{Proposition 2:}

(i) For some parameter values, conglomerates form.

(ii) Conglomerates need not be overly liquid firms.

(iii) Adding a non-financial firm to a bank may increase or decrease the debt capacity.

Proof: see the Appendix.

The first part of the proposition indicates that some synergy values are large enough to stop the conglomerate from liquidating the core banking project and renegotiating the debt on the less liquid commercial project. In some cases, synergies are valuable enough for firms in this economy to want them.

The second part of the proposition predicts the existence of "non-bank banks", institutions that retain only part of their banking activities, in that case, institutions that accept deposits only. Non-financial

7 Readers familiar with Myers and Rajan may note the added complexity that arises when synergies mean that profitability is no longer identical with debt capacity. 
firms combine with deposit taking firms, but they do not have any advantage to extend loans. This in fact became fairly common when the market discovered the one-bank loophole in the Bank Holding Company Act of 1956. The model interprets these non-bank banks as more than simply the product of regulatory arbitrage. It instead suggests they are a viable form that would arise in an unregulated market.

The last part of the proposition indicates that the conglomerate will often remain a bank and make loans. This is really a question about whether the combined entity remains overly liquid. In the Myers and Rajan paper, the overly liquid firm becomes a bank and adds illiquid loans to its portfolio until it is no longer overly liquid. Adding a non-financial firm might, but need not, soak up the excess liquidity of the core bank project. In particular, funding a non-financial firm in-house need not substitute for loans to other commercial projects. In some environments, though, such a trade-off will exist.

\section{The numerical example continued}

As we saw before, the debt capacity of the bank is $B^{b}=1$. The debt capacity of the non-financial firm when it borrows from the bank is $B_{B}^{c}=0.8$. In this case the bank asks the firm to pay $P_{2}^{c}=0.3$ in period 2 and $P_{1}^{c}=0.5$ in period 1 . When the bank combines its core project with a loan to that non-financial firm, it remains, an overly liquid firm, and its debt capacity is $B^{b l}=1.8$.

Suppose now that the bank chooses to bring the non-financial firm in-house and realise the synergies. In this case, the transformation value of the conglomerate becomes $T^{b c}=3.4+s_{2}^{b}-0.3 s_{1}^{c}$, the going concern value of it becomes $G^{b c}=5.3+0.5 s_{2}^{b}$, and the liquidation value of it becomes $L^{b c}=5.6+0.3 s_{1}^{c}$. Assuming that $s_{1}^{c}=6$ and $s_{2}^{b}=3$, then we have $T^{b c}=4.6, G^{b c}=6.8$ and $L^{b c}=7.4$. As a result, the debt capacity of the conglomerate is 4.6. Given that the conglomerate remains an overly liquid firm, and $s_{1}^{c}=6>0$, then (12a) guarantees it is optimal to form the conglomerate.

The final thing we need to address is the problem of selective liquidation. Consider the case of selectively transforming the core banking project. At period 11/2, selective transformation does not occur because (A.8) is met, $s_{2}^{b}=3 \geq-5$. Now move back to period $1 / 2$. Note that because the non-financial firm is an illiquid firm, then (A.10) applies. Selective transformation does not occur because $s_{1}^{c}=6 \geq 5.33$.

We can go further and establish that this combined entity will also make at least one loan equal to 1 unit to a firm $F$, supported by payments $P_{1}^{f}=0.7$ and $P_{2}^{f}=0.3$, and thus can be considered bank. Again we find that the transformation value, the going concern value and the liquidation value for that entity are 5.6, 6.95 and 7.7, respectively. Therefore its debt capacity is 5.6, an improvement over the combined firm without a loan. Firm $F$, if funded separately, would have a debt capacity of 0.8 ; by 
making a loan, the bank can raise $\$ 1$ and lend $\$ 1$ to that firm. In fact, the bank can make a total of four loans. After that, the added debt capacity is less than the projects can get on their own, as constraint (5) begins to bind instead of (4).

Other possibilities exist, however. For example, if we set $s_{1}^{c}=s_{2}^{b}=10$, then the conglomerate will not be overly liquid as $T^{b c}=10.4, G^{b c}=10.3$, and $L_{I}^{b c}=8.6$.

\section{Conclusions}

In seeking to understand banking and commerce, we have purposely ignored many important concerns, such as extension of the safety net, incentives to self-deal, and other adverse incentives. We have instead concentrated on the underlying economic motives that would induce banks and non-financial firms to merge. This has provided insights in several areas.

First, our model has explored the possible synergies that allow viable mergers to take place. One advantage of the model is that it concentrates attention on motives for mergers that arise purely for reasons of liquidity. By creating an internal market, merging with a non-financial firm increases the bank's efficiency in disposing of assets backing defaulted loans. Bankruptcy codes may then play a large role in determining which mergers are viable.

A concentration on liquidity also yields some insights into other sorts of synergies. These have an indirect impact on a bank's liquidity and this will impact both the viability of the merger and the structure of the resulting bank. Banks do not have an incentive to form conglomerates with just any firm that promises higher profits; the ability to separately liquidate the firms in fact imposes fairly strict requirements. The nature of the synergies also suggest that they are project specific, and consequently, though some industries may become closely associated with banking, there will also be surprises where specific firms in unlikely industries will also associate with banks.

Finally, the model demonstrates that owning a non-financial firm can act either as a substitute or a complement to commercial loans. The substitution can be so large as to stop the conglomerate from lending at all. It becomes a "non-bank bank." In actual experience, we will most likely see different banks pursuing each of these strategies. 


\section{Appendix}

\section{Proof of proposition 1 .}

(i) Following (10), reintroduced here as (A.1), we know the maximum number of loans, $n^{*}$, that the overly liquid firm $B$ can extend to liquid or illiquid firms like firm $F$.

$$
T^{b}+n^{*} B_{B}^{f}=\operatorname{Max}\left\{G^{b}+n^{*} G^{l}, L^{b}+n^{*} L^{l}\right\}
$$

Suppose that firm $B$ affiliates with a liquid or illiquid firm like firm $C$, and that this leads to an increase in fraction of the assets underlying the loans extended by the bank to firms $F$ recovered in case of liquidation. That is, it leads to an increase in $\alpha_{B}^{f}$. Suppose also that the bank does not change the size of the loans it extends to firms $F$ as a result of the synergy, that is, it keeps lending $B_{B}^{f}$ to each one of them, but it changes the time distribution of the payments it demands to these firms, $P_{1}^{f}$ and $P_{2}^{f}$. Therefore, we know, based on (7), that the debt capacity of that conglomerate, $B_{I}^{b l c}$, is

$$
B^{b l c}=\operatorname{Min}\left\{T^{b l c}, \operatorname{Max}\left(\tilde{G}^{b l c}, \tilde{L}^{b l c}\right)\right\}
$$

where

$T^{b l c} \equiv T^{b}+T^{c}+n B_{B}^{f}$

$\tilde{G}^{b l c} \equiv G^{b}+G^{c}+n a_{B}^{f} \tilde{\alpha}^{f} d_{2}^{f}$

$\tilde{L}^{b l c} \equiv L^{b}+L^{c}+n \tilde{\alpha}^{f} d_{2}^{f}$

Because $T^{c}>\operatorname{Max}\left\{G^{c}, L^{c}\right\}$, then for $n=n^{*}$ and $\tilde{\alpha}^{f}=\alpha^{f}$ we have

$$
T^{b l c}>\operatorname{Max}\left(\tilde{G}^{b l c}, \tilde{L}^{b l c}\right)
$$

As a result, the conglomerate will be able to continue funding $n^{*}$ loans of size $B_{b}^{f}$, provided that $\tilde{\alpha}^{f}$ solves (A.4)

$$
T^{b l c}=\operatorname{Max}\left\{G^{b}+G^{c}+n^{*} a_{B}^{f} \widetilde{\alpha}^{f} d_{2}^{f}, L^{b}+L^{c}+n^{*} \tilde{\alpha}^{f} d_{2}^{f}\right\}
$$

Note that in this case, the conglomerate is able to raise more money than the sum of what the bank and the non-financial firm were able to raise independently.

(ii) Now we take up the problem of selective liquidation. If the conglomerate transforms its most liquid assets, those of the bank, at period $1 \frac{1}{2}$, it receives $\alpha^{b} d_{2}^{b}$. Recall that in this case, the conglomerate's creditors will not accept renegotiation of their claims. They are better off 
seizing the loans and liquidating the assets of the non-financial firm in the conglomerate. If the conglomerate chooses instead not to selectively transform its assets, it will receive at period 2, $C_{2}^{b}+d_{2}^{b}+C_{2}^{c}+d_{2}^{c}+n^{*} \tilde{P}_{2}^{f}-P_{2}^{b l c}$, where $P_{2}^{b l c}$ is the second period payment that the conglomerate promised to pay its creditors. Given that $P_{2}^{b l c}=\alpha_{I}^{b} d_{2}^{b}+\alpha_{I}^{c} d_{2}^{c}$, selective transformation will not occur at period $1 \frac{1}{2}$ if

$$
\alpha^{b} d_{2}^{b} \leq C_{2}^{b}+d_{2}^{b}+C_{2}^{c}+d_{2}^{c}+n^{*} \tilde{P}_{2}^{f}-\alpha^{b} d_{2}^{b}-\alpha^{c} d_{2}^{c}
$$

Now move back to period $1 / 2$. If the conglomerate chooses not to selectively liquidate, it gets $C_{1}^{b}+C_{2}^{b}+d_{2}^{b}+C_{1}^{c}+C_{2}^{c}+d_{2}^{c}+n^{*}\left(\tilde{P}_{1}^{f}+\tilde{P}_{2}^{f}\right)-B^{b l c}$, where $B^{b l c}$ is the total amount that the conglomerate borrows from investors. Assuming that the conglomerate makes all the loans it can, that is, until it stops being an overly liquid firm, then we have $B^{b l c}=\tilde{T}^{b l c}$. In this case the conglomerate gets $\alpha^{b} d_{1}^{b}+\alpha^{c} d_{1}^{c}$.

If the conglomerate chooses instead to selectively liquidate the bank's core project then it gets, in case its creditors do not renegotiate, $\alpha^{b} d_{1}^{b}$. If the conglomerate's creditors do not renegotiate, that is, if they seize the conglomerate's assets when the bank transforms its core assets, they get $\alpha^{c} d_{1}^{c}+n^{*} B_{B}^{f}$, where $n^{*} B_{B}^{f}$ is the bank's portfolio of loans. If, instead, the conglomerate's creditors accept to renegotiate at period 1, then they get $\operatorname{Max}\left\{G^{c}+n^{*} G^{l}, L^{c}+n^{*} L^{l}\right\}$. Therefore, they will not renegotiate if

$$
\alpha^{c} d_{1}^{c}+n^{*} B_{B}^{f}>\operatorname{Max}\left\{G^{c}+n^{*} G^{l}, L^{c}+n^{*} L^{l}\right\}
$$

Note that if $G^{c} \leq L^{c}$, the conglomerate's creditors will not renegotiate because as we saw before, $G_{I}^{l}<L_{I}^{l}, B_{B}^{f} \geq L_{I}^{l}$. Otherwise, (A.6) imposes a lower boundary on the size of the bank's portfolio of loans for renegotiation not to occur at period 1.

When the conglomerate's creditors are not expected to renegotiate, the conglomerate will not selectively transform the bank's assets at period $1 \frac{1}{2}$ because $\alpha^{b} d_{1}^{b} \leq \alpha^{b} d_{1}^{b}+\alpha^{c} d_{1}^{c}$.

Proof of proposition 2.

(i) For the existence of conglomerates we must show that the bank does not selectively transform its core project. Start at period $1 \frac{1 / 2}{2}$. If the bank in the conglomerate does not transform its core project, the conglomerate gets $C_{2}^{b}+s_{2}^{b}+d_{2}^{b}+C_{2}^{c}+d_{2}^{c}-$ $\left(\alpha^{b} d_{2}^{b}+\alpha^{c} d_{2}^{c}\right)$. If the bank does transform the core project, the conglomerate receives $\alpha^{b} d_{2}^{b}+C_{2}^{c}-\alpha^{c} d_{2}^{c}$. Hence the bank will not selectively transform the core project if 


$$
C_{2}^{b}+s_{2}^{b}+d_{2}^{b} \geq \alpha^{b} d_{2}^{b}+\alpha^{b} d_{2}^{b}
$$

This implies a restriction on possible synergy values. Notice that $s_{1}^{c}$ value, which has already been bargained over and distributed, does not matter for renegotiation at this period. Therefore we must have

$$
s_{2}^{b} \geq\left(\alpha^{b}+\alpha^{b}-1\right) d_{2}^{b}-C_{2}^{b}
$$

Now move back to period $1 / 2$. If the bank does not transform the core asset, the conglomerate gets $C_{1}^{b}+C_{2}^{b}+s_{2}^{b}+d_{2}^{b}+C_{1}^{c}+C_{2}^{c}+d_{2}^{c}-B^{b c}$. Continuing to assume that the conglomerate remains an overly liquid firm, then using the value for $B^{b c}$ defined in (11) this reduces to $\alpha^{b} d_{1}^{b}+\alpha^{c}\left(d_{1}^{c}+s_{1}^{c}\right)$. If instead it transfers that asset at period $1 / 2$, it receives $\alpha^{b} d_{1}^{b}+C_{1}^{c}+C_{2}^{c}+d_{2}^{c}-$ $\operatorname{Max}\left\{a_{I}^{c} C_{2}^{c}+\alpha^{c} d_{2}^{c}, \alpha^{c} d_{1}^{c}\right\}$. When the non-financial firm is a liquid firm, that is, $a_{I}^{c} C_{2}^{c}+\alpha^{c} d_{2}^{c}<\alpha^{c} d_{1}^{c}$, that reduces to $\alpha^{b} d_{1}^{b}+C_{1}^{c}+C_{2}^{c}+d_{2}^{c}-\alpha^{c} d_{1}^{c}$, and selective transformation will not occur if

$$
s_{1}^{c} \geq \frac{C_{1}^{c}+C_{2}^{c}+d_{2}^{c}-\alpha^{c} d_{1}^{c}}{\alpha^{c}}-d_{1}^{c}
$$

When the non-financial firm is an illiquid firm, that is, $a_{I}^{c} C_{2}^{c}+\alpha^{c} d_{2}^{c}>\alpha^{c} d_{I}^{c}$, then the bank receives $\alpha^{b} d_{1}^{b}+C_{1}^{c}+C_{2}^{c}+d_{2}^{c}-a_{I}^{c} C_{2}^{c}-\alpha^{c} d_{2}^{c}$, if it selectively transforms its assets. Under these circumstances, selective transformation will not occur if

$$
s_{1}^{c} \geq \frac{C_{1}^{c}+C_{2}^{c}+d_{2}^{c}-a_{I}^{c} C_{2}^{c}-\alpha^{c} d_{2}^{c}}{\alpha^{c}}-d_{1}^{c}
$$

(ii) The conglomerate need not be overly liquid. Suppose the conglomerate is overly liquid, so that $T^{c}$ binds. Now look at the effect of synergies on $B^{c}$, and use $\Delta$ to denote the difference between the constraint with synergies and the constraint without synergies. Then, based on the definitions of the transformation, going concern and liquidation values, we have

(A.11) $\Delta T^{c}=s_{2}^{b}-\alpha^{f_{s}^{c}}$

(A.12) $\Delta G^{c}=a^{b} s_{2}^{b}$

(A.13) $\Delta L^{c}=\alpha^{f} s_{1}^{c}$ 
Now increase $s_{2}^{b}$ and keep $s_{1}^{c}$ constant. That means the value of (A.11) increases, as does the value of (A.12), while (A.13) remains constant. Now if $L^{c}>G^{c}$ increasing $s_{2}^{b}$ will eventually give us $T^{c}>L^{c}$ and we are done, as the conglomerate is no longer overly liquid. If $a^{f}<1$ then eventually we will get $L^{c}>G^{c}$ for large enough $s_{2}^{b}$. Finally, if neither of the above two cases holds, decrease $s_{1}^{c}$ until $G^{c}$ binds. This may cause a problem as the profit when the bank asset is not transformed

(A.14) $\quad C_{1}^{c}+C_{2}^{c}+d_{2}^{c}+C_{1}^{b}+C_{2}^{b}+s_{2}^{b}-B^{c}$

may no longer exceed the profit from transforming the bank asset,

(A.15) $\quad \alpha^{b} d_{1}^{b}+\left(C_{1}^{c}+C_{2}^{c}+d_{2}^{c}\right)-$ renegotiated debt

The value of the renegotiated debt depends on the project, being $\alpha^{c} d_{1}^{p}$ for a liquid project and $a^{c} C_{2}^{p}+\alpha^{c} d_{1}^{p}$ for an illiquid project. If this happens, increase $s_{2}^{b}$ until (A.13) > (A.14).

(iii) Analytically, this becomes a question about the ranges of $\bar{\alpha}$, the point at which the transformation constraint becomes binding. With the addition of the synergy elements, we have

$$
\bar{\alpha}=\frac{C_{1}^{f}+C_{2}^{f}+d_{2}^{f}+C_{1}^{b}+C_{2}^{b}+s_{2}^{b}+d_{2}^{b}}{d_{1}^{f}+s_{1}^{c}+d_{1}^{b}}
$$

Since both the numerator and denominator increase with the synergy, the exact results depend on the actual values taken on by the variables. It is significant to note, however, that the synergy may increase or decrease the level of $\bar{\alpha}$, and thus the number of loans that the bank may make. 


\section{References}

Barth, James R, R Dan Brumbaugh Jr and Glenn Yago (1997): "Breaching the Walls Between Banking and Commerce". Banking Strategies ,July/August, Vol. 31, pp. 47-50.

Barth, J R, D E Nolle and T N Rice (1997): "Commercial Banking Structure, Regulation and Performance: An International Comparison". Comptroller of the Currency, Working Paper No. 7.

Berlin, M, K John and A Saunders (1996): "Bank Equity Stakes in Borrowing Firms and Financial Distress". Review of Financial Studies 9, pp. 889-919.

Committee on Banking and Currency, US House of Representatives (1969): "The growth of Unregistered Bank Holding Companies - Problems and Prospects Stakes in Borrowing Firms and Financial Distress". US Government Printing Office, Washington D.C.

Dewatripont, Mathias and Jean Tirole (1994): "The Prudential Regulation of Banks". The MIT Press, Cambridge, Massachusetts.

Hart, Oliver and John Moore (1994): "A Theory of Debt Based on the Inalienability of Human Capital”. The Quarterly Journal of Economics, Vol. 109, pp. 841-79.

Houston, Joel, Christopher James and David Marcus (1997): "Capital Market frictions and the role of internal capital markets in banking”. Journal of Financial Economics, Vol. 46, pp. 135-64.

John, K, T A John and A Saunders (1994): "Universal Banking and Firm Risk Taking". Journal of Banking and Finance, Vol. 18, pp. 307-23.

Kahn, Charlie M (1993):"Project Choice, Moral Hazard and Optimal Subsidiary Structure for Intermediaries". University of Illinois Working Paper, March.

Kim, S (1992): “Corporate Financing Through a Shareholder Bank: Lessons from Japan”. Working Paper 92-03, Federal Reserve Bank of San Francisco.

Knox, John Jay (1900): "A History of Banking in the United States". Bradford Rhodes \& Company, New York.

Lamont, Owen (1997): "Cashflow and investment: evidence from internal capital markets". Journal of Finance, Vol. 52, pp. 83-109.

Loomis, Noel M (1968): "Wells Fargo". Bramhall House, New York.

Myers, Stewart C and Raghuram G Rajan (1998): “The paradox of liquidity”. The Quarterly Journal of Economics, August, Vol. 103, No. 3.

Pecchioli, R M (1987): "Prudential Supervision in Banking”. Paris: OECD.

Pozdena, R J (1991): "Why Banks Need Commerce Powers". Economic Review, Federal Reserve Bank of San Francisco, pp. 18-30.

Puri, M (1996): "Conflicts of Interest, Intermediation and the Pricing of Underwritten securities". Mimeo, Graduate School of Business, Stanford University.

Rajan, R (1992): "Conflict of Interest and the Separation of Commercial and Investment Banking". Working Paper, University of Chicago.

Santos, J A C (1999): "Bank Capital and Equity Investment Regulations". Journal of Banking and Finance, Vol. 23, No. 7, pp. 1095-1120.

Santos, J A C (1998): "Banking and Commerce: How Does the United States Compare to Other Countries?" Federal Reserve Bank of Cleveland, Economic Review, Vol. 34, No. 4, 4th Quarter, pp. 14-26.

Schuijer, J (1992): "Banks Under Stress". Paris: OECD. 
Spong, Kenneth (1990): "Banking Regulation: Its Purposes, Implementation and Effects". Third Edition, Federal Reserve Bank of Kansas City, Kansas City.

Telling, Edward R (1984): "Statement of Edward R Telling, Chairman and Chief Executive Officer, Sears, Roebuck \& Co.", in Comprehensive Reform in the Financial Services Industry. Hearings before the Committee on Banking, Housing and Urban Affairs, United States Senate, 99th congress, first session, part I. 



\section{Recent BIS Working Papers}

No.

62

March 1999

63

March 1999

64

March 1999

65

April 1999

66

April 1999

67

May 1999

68

May 1999

69

June 1999

70

June 1999

71

June 1999

72

August 1999

73

August 1999

74

August 1999

75

August 1999

76

October 1999

77

October 1999
The pricing of bank lending and borrowing: evidence from the federal funds market

Microeconomic inventory adjustment and aggregate dynamics

Precarious credit equilibria: reflections on the Asian financial crisis

Higher profits and lower capital prices: is factor allocation optimal?

Evolving international financial markets: some implications for central banks

The cyclical sensitivity of seasonality in US employment

The evolution and determinants of emerging market credit spreads in the 1990s

Credit channels and consumption in Europe: empirical evidence

Interbank exposures: quantifying the risk of contagion

The term structure of announcement effects

Reserve currency allocation: an alternative methodology

The Taylor rule and interest rates in the EMU area: a note

The dollar-mark axis

A note on the Gordon growth model with nonstationary dividend growth

The price of risk at year-end: evidence from interbank lending

Perceived central bank intervention and market expectations: an empirical study of the yen/dollar rate, 1993-96
Craig H Furfine

Jonathan McCarthy and Egon Zakrajšsek

Joseph Bisignano

P S Andersen, M Klau and E Yndgaard

William R White

Spencer Krane and William Wascher

Steven B Kamin and Karsten von Kleist

Gabe de Bondt

Craig H Furfine

Michael J Fleming and Eli M Remolona

Srichander

Ramaswamy

Stefan Gerlach and Gert Schnabel

Gabriele Galati

Henri Pagès

Craig H Furfine

Gabriele Galati and William Melick 


ISSN 1020-0959 